\title{
Comparison Methods of ELECTRE and Simple Additive Weighting (SAW) Methods in Determining the Best Employees of Reward Recipients
}

\author{
Corie Mei Hellyana ${ }^{1}$, Eva Argarini Pratama ${ }^{2}$, Saghifa Fitriana ${ }^{3}$, Fabriyan Fandi Dwi I ${ }^{4}$, Ragil \\ Wijianto $^{5}$, Vadlya Ma'arif ${ }^{6}$ \\ \{corie.cma@bsi.ac.id ${ }^{1}$, eva.eap@bsi.ac.id², saghifa.sff@nusamandiri.ac.id ${ }^{3}$ \} \\ Informatics Management Study Program of Universitas Bina Sarana informatika ${ }^{12}$, Information System \\ Study Program STMIK Nusa Mandiri Jakarta ${ }^{3456}$
}

\begin{abstract}
The concept of the Decision Support System (DSS) was first disclosed in 1971 by Michael Scoot Morton under the term Management Decision System. Then a number of companies, research institutions and universities began conducting research and building Decision Support Systems. This is also used by one of the manufacturing / Small and Medium Industries (IKM) companies in Indonesia. There are many factors that influence employee performance that depends on motivation, job satisfaction, stress levels, physical conditions of work, compensation systems, job design, and economic, technical and other aspects. In the process of determining rewards for employees based on these factors not only through one method but can be compared with other methods. Therefore, this study will compare 2 methods in the Management Decision System, namely the ELECTRE and SAW methods.
\end{abstract}

Keywords: IKM, ELECTRE Method, SAW Method.

\section{Introduction}

The Concept of Decision Support System (DSS) was first disclosed in 1971 by Michael Scoot Morton [1] under the term Management Decision System. Then a number of companies, research institutes and universities began to do research and build Decision Support System, so that the resulting product can be concluded that this system is a computer-based system intended to assist decision making in utilizing certain data and models to solve various problems unstructured. This is also used by one manufacturing company/Small and Medium Industry (IKM) in Indonesia. The existence of manufacturing-based companies is not only determined by the number of products sold in certain periods but also the performance or ability of the employees. Strict competition conditions can spur and motivate employees to improve employee performance, in competition and master market share. Companies should know what things are considered important by consumers, therefore the maximum possible company should produce the good performance in order to obtain optimal results and can give satisfaction to customers or consumers [2]. The success of a company is influenced by the performance of employees (job performance) or the work achieved by an employee in performing tasks in accordance with the responsibilities given to him. Employees are an important resource for the company because have talent, energy, and creativity that is needed

ICCSET 2018, October 25-26, Kudus, Indonesia

Copyright (C) 2018 EAI

DOI 10.4108/eai.24-10-2018.2280527 
by the organization in achieving its goal. There are many factors that affect employee performance that depends on motivation, job satisfaction, stress level, the physical condition of work, compensation system, job design, and other economic, technical and other aspects [3]. Exhaust industry in Purbalingga, Central Java, Indonesia, has been famous since 1970 with the production of approximately 595,371 units, with a production value of Rp. 81.4 billion are scattered from 173 IKM exhausts, with a workforce of more than 483 people [4]. One of IKM exhaust in Purbalingga is IKM VRC Muffler, which in this IKM has a total of 50 employees and in a day can produce 150 units of exhaust [4]. With the number of employees and production is not a bit of it will certainly provide problems also for the IKM VRC in the face of the increasing demands of competitiveness mentioned earlier. For that needed a trigger in the form of a reword for its employees as an effort to maintain \& improve the existence of its business. But in reality, with a large number of employees and the production of a lot, need the existence of the basis and consideration in the awarding of the rewording. For that, we need a method that can be used to determine the rewards to these employees, with supporting variables in accordance with the vision and mission of IKM VRC Muffler itself. With the method used in decision making at the level of management/owners of this company is then it can be ascertained that the decisions taken in determining the best employees who get rewards are objective. But one method may not necessarily be the basis of the use of the method whether it is really applicable or not. So there must be other methods used as a comparison.

\section{The Foundation's Theory and Related Research}

\subsection{Decision Support System}

Decision support systems as computer-based systems consisting of three interacting components, language systems (mechanisms for communicating between users and other decision support system components), knowledge systems (domain knowledge repositories of existing problems in decision support systems or as data or as a procedure), and the problemprocessing system (the relationship between the other two components, comprises one or more manipulation capabilities of common problems needed for decision-making) [5]

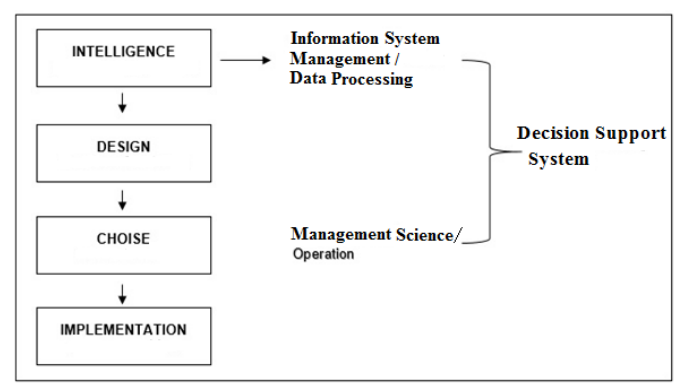

Fig. 1. Phases In The Decision Process.

2.2 


\section{Related Research}

The following is a summary of the related research that the researchers used as a guide for this study:

Table 1. Summary Of the related research.

\begin{tabular}{|c|c|c|}
\hline Tittle & Decision Support Method & Result \\
\hline $\begin{array}{l}\text { Algorithm Decision Support in } \\
\text { Determining Bidikmisi Scholarship } \\
\text { Receive (Case Study: Bidikmisi } \\
\text { Scholarship). Harahap, et all [6] }\end{array}$ & FCM and AHP & $\begin{array}{l}\text { Bidikmisi scholarship recipients using } \\
\text { FCM have data suitability with actua } \\
\text { results as many as } 489 \text { from } 804 \text { student } \\
\text { or about } 60.69 \% \text {, while the level of datc } \\
\text { compatibility using AHP is as many as } \\
590 \text { scholarship recipients or about } 73 \% \text {. }\end{array}$ \\
\hline $\begin{array}{l}\text { Management Information System } \\
\text { Employee Bonus Reward with } \\
\text { TOPSIS Method as Decision } \\
\text { Support. Albra, et all [7] }\end{array}$ & TOPSIS & $\begin{array}{l}\text { Application of Technique Ordes } \\
\text { Preference method By Similarity Tc } \\
\text { Ideal Solution is quite easy to use as } \\
\text { way to determine employees who receive } \\
\text { bonuses because the steps are quite } \\
\text { simple settlement [7] }\end{array}$ \\
\hline $\begin{array}{l}\text { Decision Support System Penilaian } \\
\text { Kinerja Karyawan Pada } \\
\text { Perusahaan Menggunakan Metode } \\
\text { Simple Additive Weighting. Abadi } \\
\text { et all [8] }\end{array}$ & $\begin{array}{l}\text { Simple Additive Weighting } \\
\text { (SAW) }\end{array}$ & $\begin{array}{l}\text { Decision Support System for Choosing } \\
\text { the Best Employees with Simple } \\
\text { gAdditive Weighting (SAW) Method car } \\
\text { be used in the calculation process tc } \\
\text { provide the best recommendations }\end{array}$ \\
\hline
\end{tabular}

\section{Methodology}

\subsection{Methods of ELECTRE}

ELECTRE is one of the multicriteria decision-making methods based on the concept of outranking by using pairwise comparisons of alternatives based on each appropriate criterion [9]. The ELECTRE method is used in conditions where alternatives that are inconsistent with the criteria are eliminated and appropriate alternatives can be generated. In other words, ELECTRE is used for cases with many alternatives but few criteria are involved. An alternative is said to dominate the other alternatives if one or more of the criteria exceed (compared to criteria of other alternatives) and equals the other remaining criteria [7]. The steps taken in solving the problem using the ELECTRE method are as follows:

\subsubsection{Step 1: Normalize the Decision Matrix}

In this procedure, each attribute is converted into a comparable value. Any normalization of 
Xy values can be done by the formula $\boldsymbol{r}_{i j}=\frac{\boldsymbol{x}_{i j}}{\sqrt{\sum_{i=1}^{m} x_{i j}^{2}}}$ for $i=1,2,3, \ldots$, m and $j=1,2,3, \ldots, \mathrm{n}$.

So obtained matrix R result of normalization,

$$
R=\left|\begin{array}{cccc}
r_{11} & r_{12} & \ldots & r_{1 n} \\
r_{21} & r_{22} & \ldots & r_{2 n} \\
\ldots & & & \\
r_{m 1} & r_{m 2} & \ldots & r_{m n}
\end{array}\right|
$$

$\mathrm{R}$ is a normalized matrix, where $\mathrm{m}$ denotes an alternative, denotes criterion and $\mathrm{r}$, is the normalization of the choice measurement of the-i, the alternative in relation to the jth criterion.

\subsubsection{Step 2: Weighting on a normalized matrix}

After normalization, each column of the matrix $\mathrm{R}$ is multiplied by the weights (WJ) determined by the decision maker. Thus, the weighted normalized matrix is $\mathrm{V}=\mathrm{RW}$ written as:

$$
\mathrm{V}=\mathrm{R} . \mathrm{W}=\left|\begin{array}{cccc}
v_{11} & v_{12} & \ldots & v_{1 n} \\
v_{21} & v_{22} & \ldots & v_{2 n} \\
\ldots & & & \\
v_{m 1} & v_{m 2} & \ldots & v_{m n}
\end{array}\right|=\left|\begin{array}{cccc}
w_{1} r_{11} & w_{2} r_{12} & \ldots & w_{n} r_{1 n} \\
w_{1} r_{21} & w_{2} r_{22} & \ldots & w_{n} r_{2 n} \\
\ldots & & & \\
w_{1} r_{m 1} & w_{2} r_{m 2} & \ldots & w_{n} r_{m n}
\end{array}\right|
$$

Where $\mathrm{W}$ is

$$
\left|\begin{array}{cccc}
w_{1} & \mathbf{0} & \ldots & \mathbf{0} \\
\mathbf{0} & w_{2} & \ldots & \mathbf{0} \\
\ldots & & & \\
\mathbf{0} & \mathbf{0} & \ldots & w_{n}
\end{array}\right|
$$

\subsubsection{Step 3: Determine the concordance and discordance set}

For each pair of alternatives, $\mathrm{k}$ and $\mathrm{I}\left(\mathrm{k}, \mathrm{I}=1,2,3, \ldots, \mathrm{m}\right.$ and $\left.\mathrm{k}^{\wedge} \mathrm{I}\right)$ A collection of criteria is divided into two subsets, namely concordance and discordance. A criterion in an alternative

includes concordance if $C_{k} i=j, V_{k j}>V_{t j}$, for $j=1,2,3, \ldots, \mathrm{n}$

Conversely, the complementary of the concordance subsets is the set of discordance, if

$D_{k t}=\left\{j, V_{k j}<V_{i j}\right\}$, for $j=1,2,3, \ldots, n$

\subsubsection{Step 4: Calculate concordance and discordance matrices}


a. Calculates the concordance matrix, to determine the value of the elements in the concordance matrix is to add the weights included in the concordance set,

$$
\text { mathematically as follows } C_{k l}=\sum_{j \in C_{k l}} w_{j}
$$

b. Calculating matrix

To determine the value of the elements in the discordance matrix is to divide the maximum of the difference of criteria belonging to the discordance set with the maximum difference of values of all the existing criteria, mathematically as follows

$$
k l=\frac{\max \left\{\left|V_{k j}-V_{l j}\right|\right\}_{j \in D_{k l}}}{\max \left\{\left|V_{k j}-V_{l j}\right|\right\}_{V_{j}}}
$$

\subsubsection{Step 5: determine the dominant matrix of concordance and discordance}

a. Calculate concordance domain matrix, matrix $\mathrm{F}$ as concordance dominant matrix can be constructed with the help of threshold value, that is by comparing every value of concordance matrix element with the threshold value $C_{k l} \geq c$

With threshold value (c) is $c=\frac{\sum_{k=1}^{m} \sum_{l=1}^{m} C_{k l}}{m(m-1)}$

So the matrix element $\mathrm{F}$ is determined as follows $f_{k l}=\left\{\begin{array}{c}1, \text { Jika } C_{k l} \geq c \\ 0, \text { if } C_{k l} \leq c\end{array}\right.$

b. Calculate the discordance domain matrix

The matrix $\mathrm{G}$ as the dominant matrix of discordance can be constructed with the help

of the threshold value $d=\frac{\sum_{k=1}^{m} \sum_{l=1}^{m} d_{k l}}{m(m-1)}$

And the matrix element $G$ is determined as follows $g_{k l}=\left\{\begin{array}{l}1, \text { if } d_{k l} \geq d \\ 0, \text { if } d_{k l} \leq d\end{array}\right.$

\subsubsection{Step 6: Determine the aggregate dominance matrix}

The matrix $\mathrm{E}$ as an aggregate dominance matrix is a matrix whose elements are multiplicates of matrix elements $\mathrm{F}$ with matrices of matrices materially matrix $\mathrm{G}$ can be expressed as

${ }^{e} k l=f k l^{x} d k l$

\subsubsection{Step 7: Elimination of less favorable alternatives}

Matrix E gives the order of choice of each alternative, ie when Ekt $=1$ then alternative Ak is a better alternative than $\mathrm{A}$. Thus, the row in the matrix $\mathrm{E}$ which has the least amount of $\mathrm{Akt}=1$ can be eliminated. Thus the best alternative is the alternative that dominates other alternatives.

a. Simple Additive Weighting Method 
Simple Additive Weighting (SAW) method is one of the methods of Multi-Attribute Decision Making (MADM). This method is also often known as the weighted summing method. The basic concept of the SAW method is to find the weighted sum of performance ratings on each alternative in all attributes [10].

Under the name, Simple Additive Weighting method can be interpreted as a simple weighting method or a weighted sum on problem-solving in a decision support system. The concept of this method is to search for a performance rating (priority scale) on each alternative across all attributes. The algorithm of completion of this method is as follows:

1) Step 1: Define in advance the criteria that will be made as a benchmark problem solving

2) Step 2 : Normalize each alternative value on each attribute by calculating the performance rating value

3) Step 3: Calculate the preference weight value on each alternative

4) Step 4: Perform ranking

The formula used in the simple additive weighting method is:

1) Normalize each alternating (calculate the performance rating value

$$
\mathrm{R}_{\mathrm{ij}}=\left\{\begin{array}{c}
\frac{x i j}{M a x x i j} \text { if } j \text { is a benefit attribute (benefit) } \\
\frac{\text { Min } x i j}{x i j} \text { if } j \text { is a cost attribute (cost) }
\end{array}\right.
$$

2) Calculates the value of preference weights on each alternative

$$
\mathrm{V}_{\mathrm{i}}=\sum_{j=1}^{n} W j R_{i j}
$$

Information:

$\mathrm{Vi}=$ Preferred Weight Value of each alternative

$\mathrm{Wj}=$ Weight Criteria Value

Rij = Performance Rating Value

b. Research Mindset 


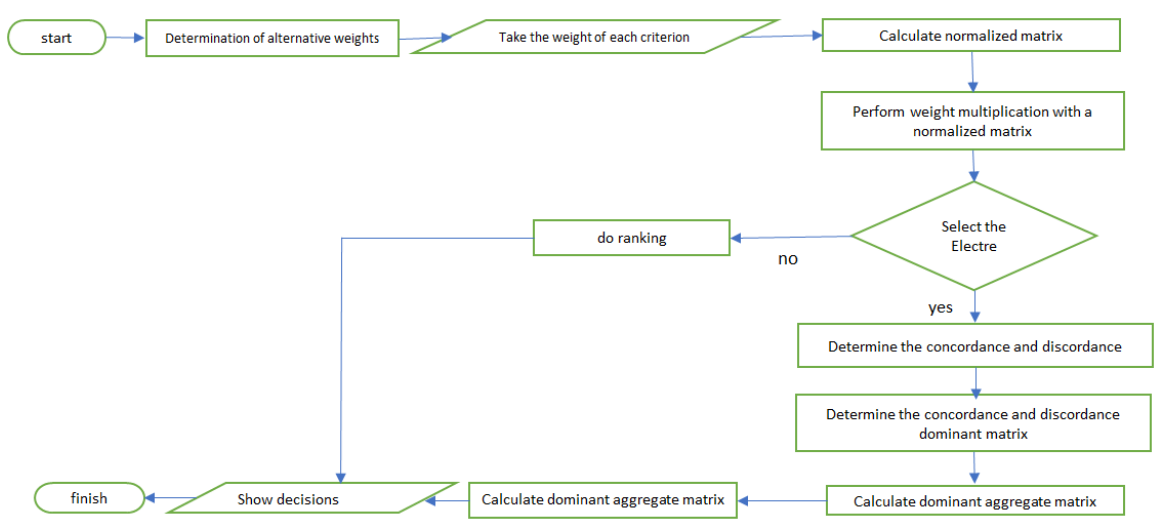

Fig. 2. Research Mindset.

\section{Result and Discussion}

\subsection{Problem Analysis}

Problem analysis can be said as a process to find the cause of the problem. In conducting the selection of housing, people find it difficult to consider some housing according to the required and desired criteria. So that the selection process takes a long time, and must be really careful if the alternative housing has the same amount of value.

\subsection{Criteria Analysis}

In this calculation process, the required criteria that will be used as material calculation can be seen in the following table:

Table 1. Criteria.

\begin{tabular}{cc}
\hline Criteria & Information \\
\hline $\mathrm{C} 1$ & Employee Motivation \\
$\mathrm{C} 2$ & Organizational Culture \\
$\mathrm{C} 3$ & Employee Job Satisfaction \\
$\mathrm{C} 4$ & Employee Performance \\
\hline
\end{tabular}

In this study used to sample data 4 employees (A1, A2, A3, A4) as an alternative to performing manual calculations by ELECTRE and SAW methods. The match rating table of each alternative on each criterion. 
Table 2. Rating compatibility.

\begin{tabular}{ccccc}
\hline \multirow{2}{*}{ Alternative } & \multicolumn{4}{c}{ Criteria } \\
\cline { 2 - 5 } & C1 & C2 & C3 & C4 \\
\hline A1 & 3 & 4 & 4 & 4 \\
A2 & 5 & 4 & 4 & 5 \\
A3 & 4 & 4 & 3 & 3 \\
A4 & 5 & 5 & 5 & 5 \\
\hline
\end{tabular}

Decision-making giving preference weights as: $\mathrm{W}=(4,3,3,5)$. The decision matrix formed from the table matches are as follows:

$$
X=\left[\begin{array}{llll}
3 & 4 & 4 & 4 \\
5 & 4 & 4 & 5 \\
4 & 4 & 3 & 3 \\
5 & 5 & 5 & 5
\end{array}\right]
$$

\subsection{Method of ELECTRE}

To solve the above problem with the ELECTRE method will be done with the steps previously described:

1. Normalization of the decision matrix is:

$R=\left[\begin{array}{llll}0,3464 & 0,4682 & 0,4924 & 0,4619 \\ 0,5774 & 0,4682 & 0,4924 & 0,5774 \\ 0,4619 & 0,4682 & 0,3693 & 0,3464 \\ 0,5774 & 0,5852 & 0,6155 & 0,5774\end{array}\right]$

2. Weighting on a normalized matrix

$$
\mathrm{V}=\left[\begin{array}{llll}
1,3856 & 1,4045 & 1,4771 & 2,3094 \\
2,3094 & 1,4045 & 1,4771 & 2,8868 \\
1,8475 & 1,4045 & 1,1078 & 1,7321 \\
2,3094 & 1,7556 & 1,8464 & 2,8868
\end{array}\right]
$$

3. Determining the set of concordance and discordance

a. Concordance, A criterion in an alternative included in concordance is $\mathrm{C}_{\mathrm{kl}}=$ $\left\{j, V_{k j} \geq V_{i j}\right\}$, for $\mathrm{j}=1,2,3, \ldots, \mathrm{n}$. The result is:

\begin{tabular}{|c|c|c|c|c|c|c|c|c|c|c|c|c|}
\hline $\mathrm{C}_{\text {ld }}$ & $\mathrm{C}_{12}$ & $\mathrm{C}_{13}$ & $\mathrm{C}_{14}$ & $\mathrm{C}_{21}$ & $\mathrm{C}_{23}$ & $\mathrm{C}_{24}$ & $\mathrm{C}_{31}$ & $\mathrm{C}_{32}$ & $\mathrm{C}_{34}$ & $\mathrm{C}_{41}$ & $\mathrm{C}_{42}$ & $\mathrm{C}_{43}$ \\
\hline Assosiation & $\{2,3\}$ & $\{2,3,4\}$ & \{\} & $\{1,2,3,4\}$ & $\{1,2,3,4\}$ & $\{1,4\}$ & $\{1,2\}$ & $\{2\}$ & \{\} & $\{1,2,3,4\}$ & $\{1,2,3,4\}$ & $\{1,2,3,4\}$ \\
\hline
\end{tabular}

b. Discordance, A criterion in an alternative if $\mathrm{D}_{\mathrm{kl}}=\left\{j, V_{k j}<V_{i j}\right\}$, for $\mathrm{j}=$ $1,2,3, \ldots, n$. The result is:

\begin{tabular}{|c|c|c|c|c|c|c|c|c|c|c|c|c|}
\hline $\mathrm{D}_{1 \mathrm{~d}}$ & $\mathrm{D}_{12}$ & $\mathrm{D}_{13}$ & $\mathrm{D}_{14}$ & $\mathrm{D}_{21}$ & $\mathrm{D}_{23}$ & $\mathrm{D}_{24}$ & $\mathrm{D}_{31}$ & $\mathrm{D}_{32}$ & $\mathrm{D}_{34}$ & $\mathrm{D}_{41}$ & $\mathrm{D}_{42}$ & $\mathrm{D}_{43}$ \\
\hline Assosiation & $\{1,4\}$ & $\{1\}$ & $\{1,2,3,4\}$ & \{\} & \{\} & $\{2,3\}$ & $\{3,4\}$ & $\{1,3,4\}$ & $\{1,2,3,4\}$ & \{\} & \{\} & \{\} \\
\hline
\end{tabular}


4. Calculating concordance and discordance matrices

a. Concordance Matrix, Calculates the concordance matrix by the formula $\mathrm{C}_{\mathrm{kl}}=$ $\sum_{j C_{w}} W_{j}$. Generate a matrix:

\begin{tabular}{|c|c|c|c|}
\hline- & 6 & 11 & 0 \\
\hline 15 & - & 15 & 9 \\
\hline 7 & 3 & - & 0 \\
\hline 15 & 15 & 15 & - \\
\hline
\end{tabular}

b. Discordance Matrix

To calculate the value of the elements in the discordance matrix is to divide the maximum difference of the criterion value included in the discordance subset by the maximum difference of the value of all the existing criterion by the formula: $\mathrm{D}_{\mathrm{kl}}=\frac{\left\{\max \left(v_{m n}-v_{m n-l n}\right)\right\} ; m, n \in D_{k l}}{\left\{\max \left(v_{m n}-v_{m n-l n}\right)\right\} ; m, n=1,2,3, \ldots}$.

Generate a matrix :

\begin{tabular}{|c|c|c|c|}
\hline- & 1 & 1 & 1 \\
\hline 0 & - & 0 & 1 \\
\hline 1 & 1 & - & 1 \\
\hline 0 & 0 & 0 & - \\
\hline
\end{tabular}

5. Determine the threshold of the dominant matrix of concordance and discordance.

The threshold is obtained from the sum of all elements of the matrix divided by the matrix size. Calculate the dominant matrix of concordance using the equation:

$c=\frac{6+11+15+15+9+7+3+15+15+15}{12}=9,25$, so the concordance matrix is:

$\mathrm{F}=\left[\begin{array}{cccc}- & 0 & 0 & 0 \\ 1 & - & 1 & 0 \\ 0 & 0 & - & 0 \\ 1 & 1 & 1 & -\end{array}\right]$

Calculates the dominant matrix of discordance $\mathrm{d}=\frac{1+1+1+0+0+1+1+1+1+0+0+0}{12}=$ 0,5833 , so the discordance matrix is:

$G=\left[\begin{array}{cccc}- & 0 & 0 & 0 \\ 1 & - & 1 & 0 \\ 0 & 0 & - & 0 \\ 1 & 1 & 1 & -\end{array}\right]$

6. Determine the aggregate dominance matrix

$\mathrm{E}=\mathrm{F} X \mathrm{G}$ 
$=\left[\begin{array}{cccc}- & 0 & 0 & 0 \\ 1 & - & 1 & 0 \\ 0 & 0 & - & 0 \\ 1 & 1 & 1 & -\end{array}\right] X\left[\begin{array}{cccc}- & 0 & 0 & 0 \\ 1 & - & 1 & 0 \\ 0 & 0 & - & 0 \\ 1 & 1 & 1 & -\end{array}\right]=\left[\begin{array}{cccc}- & 0 & 0 & 0 \\ 0 & - & 0 & 0 \\ 0 & 0 & - & 0 \\ 0 & 0 & 0 & -\end{array}\right]$

Thus, the aggregate dominance matrix is:

$\mathrm{E}=\left[\begin{array}{cccc}- & 0 & 0 & 0 \\ 0 & - & 0 & 0 \\ 0 & 0 & - & 0 \\ 0 & 0 & 0 & -\end{array}\right]$

Because the value of $E=0$, then used how to add the value on the line:

\begin{tabular}{|c|c|c|c|c|c|}
\hline Alternative & & & & & FinalResult \\
\hline A1 & 1,3856 & 1,4045 & 1,4771 & 2,3094 & 6,5766 \\
\hline A2 & 2,3094 & 1,4045 & 1,4771 & 2,8868 & 8,0777 \\
\hline A3 & 1,8475 & 1,4045 & 1,1078 & 1,7321 & 6,0919 \\
\hline A4 & 2,3094 & 1,7556 & 1,8464 & 2,8868 & 8,7981 \\
\hline
\end{tabular}

7. Elimination of less favorable alternatives

Matrix E gives a sequence of options from each alternative, ie when $e_{k l}=1$ then alternative $\mathrm{Ak}$ is a better alternative than $\mathrm{A}$. So the row in the matrix $\mathrm{E}$ which has the least amount of $\mathrm{e}_{\mathrm{kl}}=1$ can be eliminated.

However, since $e_{k l} \neq 1$ then the value of each row in step 2 is summed, and the highest value is the best alternative. The best alternative is Hasbi Assidik with value 8,7981, so Hasbi Assidik selected to get the reward.

\subsection{SAW Method}

To solve the above problem using the SAW method will be done in accordance with the steps:

1. Perform normalization on each alternative value on each attribute by calculating the value of performance rating;

\begin{tabular}{|c|c|}
\hline R11 & $=3 / \max \{3 ; 5 ; 4 ; 5\}=0,6$ \\
\hline R21 & $=5 / \max \{3 ; 5 ; 4 ; 5\}=1$ \\
\hline R31 & $=4 / \max \{3 ; 5 ; 4 ; 5\}=0,8$ \\
\hline R41 $=5 / \max \{3 ; 5 ; 4 ; 5\}=1$ \\
\hline R12 $=4 / \max \{4 ; 4 ; 4 ; 5\}=0,8$ \\
\hline R22 $=4 / \max \{4 ; 4 ; 4 ; 5\}=0,8$ \\
\hline R32 $=4 / \max \{4 ; 4 ; 4 ; 5\}=0,8$ \\
\hline R42 $=5 / \max \{4 ; 4 ; 4 ; 5\}=1$ \\
\hline
\end{tabular}

\begin{tabular}{|c|c|}
\hline R13 & $=4 / \max \{4 ; 4 ; 3 ; 5\}=0,8$ \\
\hline R23 & $=4 / \max \{4 ; 4 ; 3 ; 5\}=0,8$ \\
\hline R33 & $=3 / \max \{4 ; 4 ; 3 ; 5)=0,6$ \\
\hline R34 $=5 / \max \{4 ; 4 ; 3 ; 5\}=1$ \\
\hline R14 $=4 / \max \{4 ; 5 ; 3 ; 5\}=0,8$ \\
\hline R24 $=5 / \max \{4 ; 5 ; 3 ; 5\}=1$ \\
\hline R34 $=3 / \max \{4 ; 5 ; 3 ; 5\}=0,6$ \\
\hline R44 $=5 / \max \{4 ; 5 ; 3 ; 5\}=1$ \\
\hline
\end{tabular}

Thus, the normalized performance matrix is obtained:

$\mathrm{R}=\left[\begin{array}{cccc}0,6 & 0,8 & 0,8 & 0,8 \\ 1 & 0,8 & 0,8 & 1 \\ 0,8 & 0,8 & 0,6 & 0,6 \\ 1 & 1 & 1 & 1\end{array}\right]$ 
2. The next step is to calculate the value of preference weight in each alternative:

$$
\begin{aligned}
& \mathrm{V}_{1}=\left(\mathrm{W}_{1} * \mathrm{R}_{11}\right)+\left(\mathrm{W}_{2} * \mathrm{R}_{12}\right)+\left(\mathrm{W}_{3} * \mathrm{R}_{13}\right)+\left(\mathrm{W}_{4} * \mathrm{R}_{14}\right)=(4 * 0,6)+(3 * 0,8)+(3 * 0,8)+(5 * 0,8)=11,2 \\
& \mathrm{~V}_{2}=\left(\mathrm{W}_{1} * \mathrm{R}_{21}\right)+\left(\mathrm{W}_{2} * \mathrm{R}_{22}\right)+\left(\mathrm{W}_{3} * \mathrm{R}_{23}\right)+\left(\mathrm{W}_{4} * \mathrm{R}_{24}\right)=(4 * 1)+(3 * 0,8+(3 * 0,8)+(5 * 1)=13,8 \\
& \mathrm{V}_{3}=\left(\mathrm{W}_{1} * \mathrm{R}_{31}\right)+\left(\mathrm{W}_{2} * \mathrm{R}_{32}\right)+\left(\mathrm{W}_{3} * \mathrm{R}_{33}\right)+\left(\mathrm{W}_{4} * \mathrm{R}_{34}\right)=(4 * 0,8)+(3 * 0,8)+(3 * 0,6)+(5 * 0,6)=10,4 \\
& \mathrm{~V}_{4}=\left(\mathrm{W}_{1} * \mathrm{R}_{41}\right)+\left(\mathrm{W}_{2} * \mathrm{R}_{42}\right)+\left(\mathrm{W}_{3} * \mathrm{R}_{43}\right)+\left(\mathrm{W}_{4} * \mathrm{R}_{44}\right)=(4 * 1)+(3 * 1)+(3 * 1)+(5 * 1)=15
\end{aligned}
$$

3. Conduct ranking based on the preference weight value.

Based on the calculation of Vi, seen the value of V4 has the greatest value of 15 . This can be interpreted that the value of V4 in this employee Hasbi Asidik became entitled to get recommendations to receive rewards from the company.

\section{Conclusion}

From the results of research on Determination of the Best Employee of Reward Receiver Using Elimination and Choice Translation Reality (ELECTRE) Method, it can be concluded as follows:

1. ELECTRE and SAW methods can be used as a reference method that can be used to determine the best employees to receive rewards from the company award.

2. Based on research that has been done either using the method of ELECTRE or SAW, Hasbi Asidik employees who received recommendations to receive rewards from the company.

Some suggestions that need to be considered for the attention to be done and studied in future research are as follows:

1. The next research can use the ELECTRE method with different IKM so that the result can be compared with this research.

2. Can add other variables in the object of research so that later results obtained will be more accurate.

\section{References}

[1] E. dan J. E. Turban, "Decision Support Systems and Intelligent Systems”,. Aronson, 6th edition, Copyright 2001. Prentice Hall, Upper Saddle River, 2001.

[2] S. G., Manajemen Sumber Daya Manusia (Human Resource) Suatu Pendekatan Mikro. Jakarta: Djanbatan, 2000.

[3] T. H. Hadoko, Manajemen Personalia dan Sumber Daya Manusia. Yogyakarta: BPFEYogyakarta, 2003.

[4] Hardiyanto, "Produk Industri Knalpot Purbalingga Capai 595.371 Unit Per Tahun," 2015. [Online]. Available: http://plid.purbalinggakab.go.id/produk-industri-knalpot-purbalingga-capai-595371-unit-per-tahun/. [Accessed: 15-Mar-2018].

[5] D. Nofriansyah, Konsep Data Mining Vs Sistem Pendukung Keputusan. Yogyakarta: Depublisher, 2015.

[6] H. E. Harahap, F. Bukhari, and B. P. Silalahi, "Algorithm Decision Support in Determining Bidikmisi Scholarship Receive ( Case Study : Bidikmisi Scholarship ),” Int. J. Eng. Manag. Res., vol. 8, no. 1, pp. 217-222, 2018. 
[7] W. Albra, M. Heikal, M. Khaddafi, A. Apridar, D. Damanhur, and I. Ichsan, "Management Information System Employee Bonus Reward with TOPSIS Method as Decision Support," IJSRST, vol. 3, no. 8, pp. 570-574, 2017.

[8] S. Abadi, F. Latifah, K. Kunci, S. Pendukung Keputusan, and P. Kinerja Karyawan, "Decision Support System Penilaian Kinerja Karyawan Pada Perusahaan Menggunakan Metode Simple Additive Weighting,” J. TAM (Technology Accept. Model., vol. 6, no. Juli, pp. 37-43, 2016.

[9] H. T. Mursetyo, "Penggunaan Metode Electre pada Sistem Pendukung Keputusan Pemilihan Rumah (Studi Kasus Pada PT. YEKAPE)," STIKOM Surabaya, 2010.

[10] Y. C. Saununu, "Rancang Bangun Sistem Pendukung Keputusan Pemilihan Mobil pada Showroom Mobil Menggunakan Metode Electre (Studi Kasus di Showroom Mobil Istana Megah)," STIKOM Surabaya, 2009. 